\title{
Spółka autorska MiK Piechotkowie
}

\section{Michał Piechotka, Maciej Piechotka}

Maria Kazimiera Piechotka z d. Huber ur. 12 lipca 1920 r. w Krakowie; zm. 28 listopada 2020 r. w Warszawie. Dzieciństwo i młodość spędziła w Tarnowie. Chodziła do szkoły ss. Urszulanek. Należała do harcerstwa. Maturę zdała w 1938 r., w tym samym roku rozpoczęła studia na Wydziale Architektury Politechniki Warszawskiej. W czasie wojny pracowała jako technik budowlany, a od 1942 r. kontynuowała studia na Tajnym Wydziale Architektury w Warszawie. Uczestniczyła w Powstaniu Warszawskim. W czasie Powstania wyszła za mąż za Kazimierza Macieja Piechotkę. Była więźniem obozu jeńców wojennych AK w Zeithain. Po powrocie do Polski w maju 1945 r. podjęła prace w Pracowni Konserwacji Zabytków i kontynuację studiów. Dyplom na Wydziale Architektury Politechniki Warszawskiej obroniła w 1948 r. Od 1947 r.

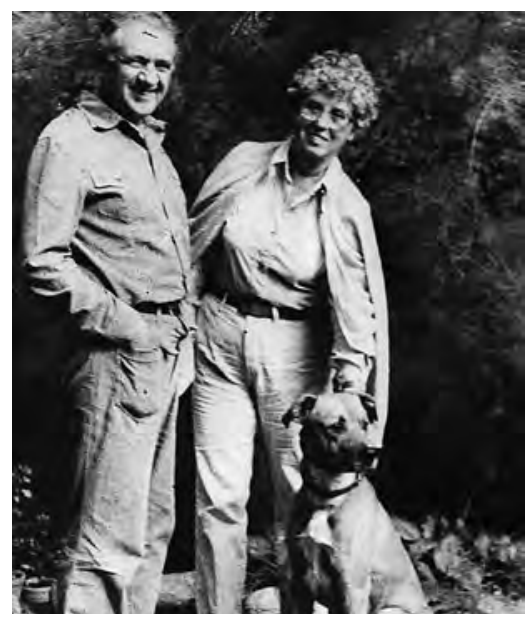

Ryc. 1. Maria i Kazimierz Piechotkowie

Fot: K. Bałuk/Biblioteka Główna; Politechnika Warszawska pracowała z mężem jako spółka autorska (ryc. 1).

Kazimierz Maciej Piechotka ur. 19 listopada 1919 r. w Warszawie; zm. 6 marca 2010 r. w Warszawie. Tu chodził do szkoły i w 1937 r. zdał maturę w gimnazjum im. Gen. J. Sowińskiego. Należał do harcerstwa. Studia na Wydziale Architektury Politechniki Warszawskiej rozpoczął 1937 r. Będąc studentem 2. roku studiów został asystentem w Zakładzie Architektury Polskiej. Podczas wojny kontynuował studia na Tajnym Wydziale Architektury Politechniki Warszawskiej. Pracował w ZAP. Jako członek AK pracował w Pracowni Legalizacji "Gajewski". W Powstaniu walczył w plutonie „Agaton” Batalionu „Pięśćc Zgrupowania „Radosław”. Za udział w konspiracji i Powstaniu został odznaczony Orderem Wojennym Virtuti Militari V kl., Krzyżem Walecznych i Brązowym Krzyżem Zasługi z Mieczami. W czasie Powstania zawarł związek małżeński z Marią Kazimiera Huber. Po Powstaniu był więźniem obozu jeńców wojennych AK w Zeithain. Po powrocie do Polski w maju 1945 r. podjął prace w Biurze Odbudowy Stolicy, prace asystenta w ZAP i kontynuował studia. W 1946 r. uzyskuje dyplom na Wydziale Architektury Politechniki Warszawskiej. Od 1947 r. pracowali z żoną Marią jako spółka autorska. W latach 1950-1970 był przewodniczącym Sekcji Budownictwa Osiedlowego SARP, a w latach 1956 -1958 wiceprezesem ds. twórczości ZG SARP. 
Od 1947 r. pracują wspólnie. Są autorami m.in. zespołu osiedli bielańskich w Warszawie i systemu otwartego budownictwa z elementów wielkowymiarowych W70 i Wk70 oraz prac teoretycznych z dziedziny budownictwa, typizacji otwartej i projektowania systemowego. Powstają liczne publikacje na tematy związane z budownictwem mieszkaniowym oraz historią osadnictwa żydowskiego, architektury i sztuki bóżniczej w Rzeczypospolitej Przedrozbiorowej.

Odznaczeni m.in.: Krzyżem Kawalerskim Orderu Polonia Restituta (1974), laureaci Nagrody m.st. Warszawy (1956); Nagrody I stopnia Prezesa Komitetu Urbanistyki i Architektury (1956); Nagrodą Ministra Budownictwa i Przemysłu Materiałów Budowlanych (1967 i 1969); Nagrodą Państwową II stopnia (1974); Status Twórcy został im przyznany przez Ministra Kultury w $1981 \mathrm{r}$.

Za prace nad architekturą żydowska, starania nad pokazaniem historii wielokulturowej i otwartej, tolerancyjnej Polski, zostali uhonorowani licznymi nagrodami: Nagrodą Jana Karskiego i Poli Nireńskiej przyznaną przez YIVO w Nowym Jorku (2000); Nagrodą im. Jana Zachwatowicza przyznana przez Polski Komitet Międzynarodowej Rady Ochrony Zabytków ICOMOS (2004). Już po śmierci męża, Maria otrzymała w 2016 r. nagrodę Fundacji Taubego im. Ireny Sendlerowej; Złoty Medal Gloria Artis przyznany przez Ministra Kultury i Dziedzictwa Narodowego w 2015 r.; Honorowe członkostwo Polskiego Instytutu Badań nad Sztuką Świata w 2015 r.

Ponadto w 2018 r. otrzymała nagrodę Specjalną Bielańskiej Gali Kultury. Dużą satysfakcję sprawiło jej powstanie z inicjatywy mieszkańców „Piechotkowa” nieformalnej nazwy dla jednego z bielańskich osiedli projektowanego przez Marię i Kazimierza Piechotków. Wszystkie nagrody i wyróżnienia przyjmowała jako wspólne z mężem.

W 2007 r. we wstępie do wystawy:

Maria i Maciej Piechotkowie: 70 lat $z$ architektura, Maria pisała:

„Należymy do ostatnich, bardzo już nielicznych architektów odchodzącego pokolenia, którzy urodzeni wkrótce po I wojnie światowej, studia architektoniczne rozpoczęli jeszcze w Polsce międzywojennej, kontynuowali w czasie wojny w szczególnych warunkach tajnego nauczania, równolegle ze służba w ZWZ AK. Przerwało je Powstanie Warszawskie, po nim pobyt w obozie jeńców wojennych w Niemczech, skąd natychmiast po zakończeniu wojny, pierwszym możliwym transportem wróciliśmy do Warszawy. Od razu przystapiliśmy do kończenia studiów - równocześnie rozpoczynając pracę zawodowa, która prowadziliśmy potem intensywnie aż do osiagnięcia wieku emerytalnego w 1980 r. Można więc powiedzieć, że cała nasza działalność projektowa mieściła się w całości w ramach czasowych PRLi była nią uwarunkowana. Jest to więc rozdział zamknięty, okres, również w naszej dziedzinie - budownictwa mieszkaniowego, bez głębszej analizy i dyskusji odsądzony od czci i wiary, skwitowany dwoma dziennikarskimi hasłami: „najpierw wstrętny, narzucony przez Moskwę socrealizm”, potem „ohydne bieda - blokowiska z wielkiej płyty, która jest przyczyną wszelkiego zła”, nawet tam, gdzie stosowano budynki typowe, realizowane najbardziej tradycyjnymi, rzemieślniczymi metodami. 
Mimo że od upadku PRL upłynęło już blisko 20 lat, nikt tego problemu dotąd głębiej, wszechstronnie nie przeanalizował, nie ocenił rzeczowo jego niewatpliwych wad, ale i ewentualnych stron dodatnich, zwłaszcza w porównaniu ze stanem obecnym.

Zaraz po powrocie do Polski, Maciej podjał pracę w BOS i był asystentem w ZAP, tam była nasza pracownia projektowa, w niej wykonywaliśmy m.in. pod kierunkiem prof. J. Zachwatowicza studia do projektu odbudowy Katedry św Jana. W pierwszych latach powojennych tematyka naszych działań była bardzo szeroka i zróżnicowana. Istniała jeszcze możliwość równoczesnej pracy w wielu miejscach, także na własną rękę. Korzystaliśmy z niej szeroko. Po stosunkowo krótkim okresie pracy przy odbudowie zabytków, Macieja w Biurze Odbudowy Stolicy (BOS), i mojej w pierwszej Państwowej Pracowni Konserwacji Zabytków (PPKZ), prowadziliśmy już wspólnie na zamówienie różnych zleceniodawców, głównie Ministerstwa Odbudowy a zwłaszcza Ministerstwa Kultury, prace naukowo-badawcze o różnej tematyce, opracowaliśmy plany urbanistyczne małych miasteczek, projekty budynków mieszkalnych, obiektów użyteczności publicznej różnego rodzaju i wielkości - poczynając od zakończonych realizacja projektów odbudowy i adaptacji dwóch zabytkowych kamienic przy ul. Długiej i Podwale w Warszawie na potrzeby Zjednoczenia Przemysłu Muzycznego, biurowca Polskiego Towarzystwa Muzycznego w Krakowie łącznie z projektami wnętrz i mebli, Domu Kultury w Zotoryji i pięciu małych miasteczkach Polski Południowej do założeń programowych i koncepcji gmachu Banku Gospodarstwa Krajowego w Gdańsku, hotelu Orbis, Muzeum Archeologicznego, Centralnego Domu Kultury w Warszawie (oczywiście nie tego, który wkrótce zaprojektowali i wybudowali w darze towarzysze radzieccy). Sprawdzaliśmy nasze możliwości w konkursach. Uzyskaliśmy m.in. wyróżnienie w pierwszym ogłoszonym w 1945 konkursie na Pomnik Powstania Warszawskiego, III nagrodę na Centralny Dom Towarowy, I nagrodę w konkursie na projekt Ministerstwa Rolnictwa (żaden z nich nie został zrealizowany). Rozpoczęliśmy zbieranie materiałów do książki o bóżnicach drewnianych.

Na przełomie lat 1940/50 sytuacja uległa zasadniczej zmianie. Przestał istnieć wolny rynek projektowy. Jedynym możliwym miejscem pracy twórczej dla architektów stały się wielkie państwowe biura projektowe. Maciej został obwiniony przez organizacje partyjną na Wydziale Architektury o propagowanie potępianych przez ówczesne władze: konstruktywizmu, funkcjonalizmu i literatury anglosaskiej, uznany za „element obcy ideologicznie” odszedł z uczelni. Zostaliśmy pracownikami Miastoprojektu Stolica Północ. Otrzymane przez nas w 1951 r. zlecenie na kompleksowe opracowanie projektu Bielan I zdecydowało, że odtąd podstawową dziedziną naszej działalności projektowej stało się budownictwo mieszkaniowe, szeroko rozumiane, od koncepcji urbanistycznej osiedla po detal architektoniczny budynku. Nastapiło to w czasie pełnego obowiązywania tzw. socrealizmu, który rozpoczął się w 1948 r. Krajową Partyjną Naradą Architektów, a zakończył Krajową Naradą Architektów, zorganizowana przez SARP w 1956 r. Nas dotknął w stosunkowo niewielkim stopniu, bo nie zajmowaliśmy się już wówczas projektowaniem obiektów o znaczeniu prestiżowym dla ustroju. Mimo to, w projektach zabudowy wzdłuż głównych ulic Bielan: Alei Zjednoczenia 
i Kasprowicza musieliśmy się częściowo do jego zasad dostosować. Inaczej po prostu projekty nie zostałyby zatwierdzone. Staraliśmy się stosować formy możliwie proste, o niewielkiej skali, nawiązujące do warszawskiego klasycyzmu. Nasze rozwiązania zostały przez władze zatwierdzające uznane za „skromne, ale na Bielanach, ze względu na ich peryferyjne usytuowanie dopuszczalne" (ryc. 2-4).

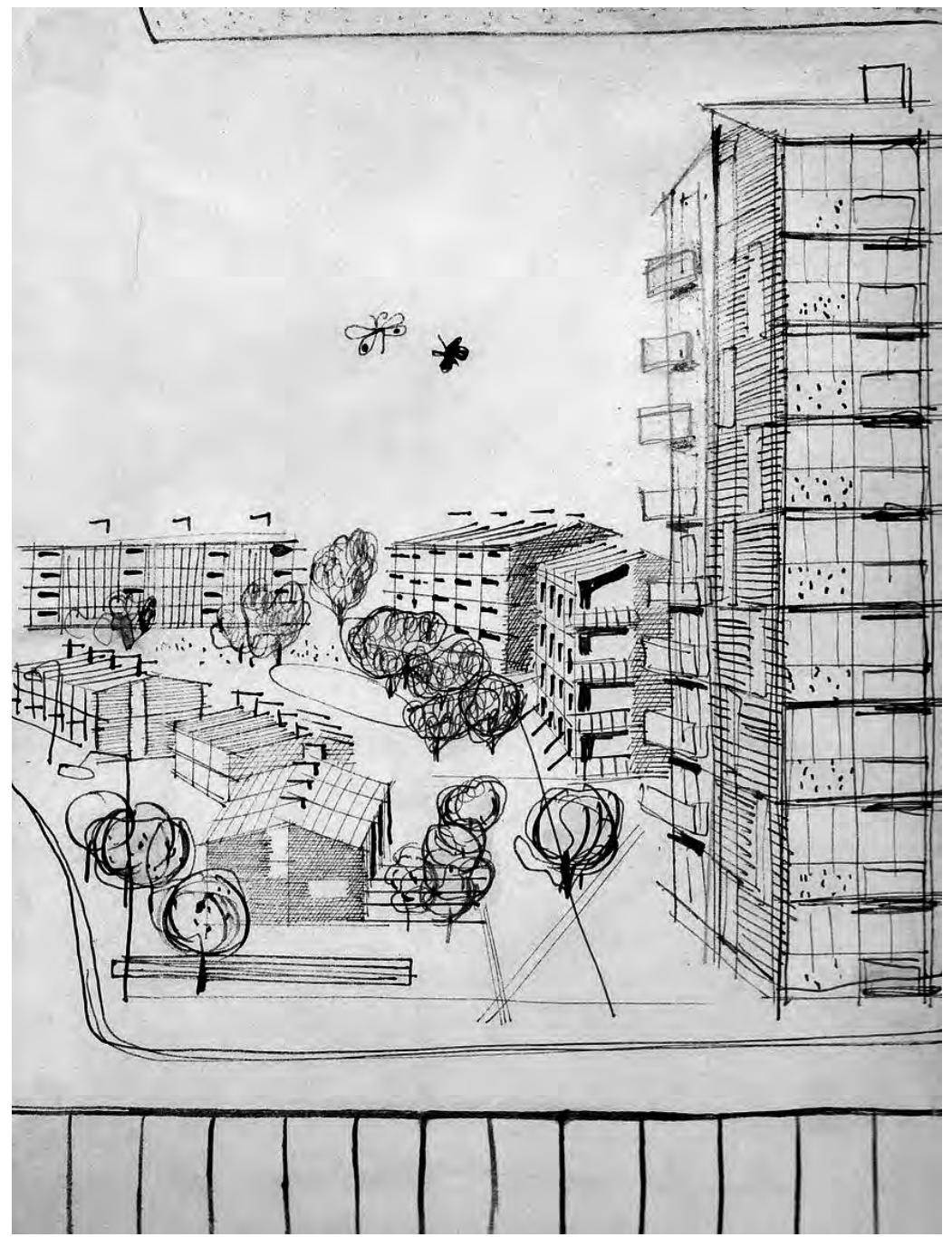

Ryc. 2. Bielany II, rysunek K. Piechotka

Źródło: $z$ archiwum rodzinnego 


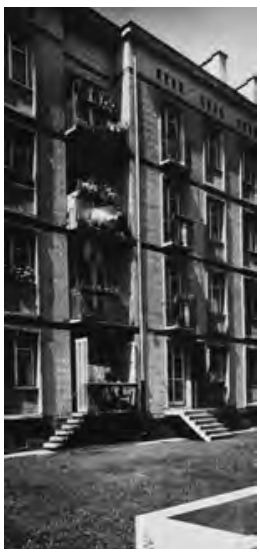

Fot. E. Kupiecki Bielany, 1958

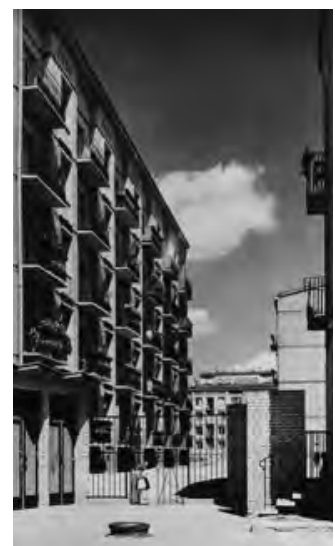

Fot. E. Kupiecki Bielany, 1958

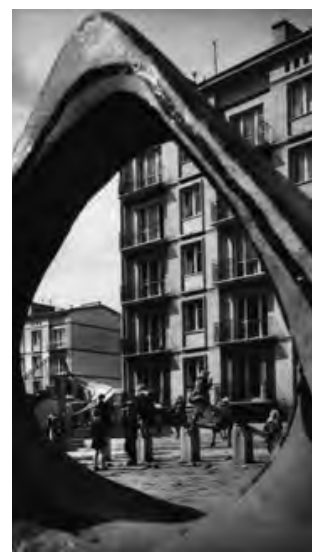

Fot. Z. Siemaszko Bielany, 1961

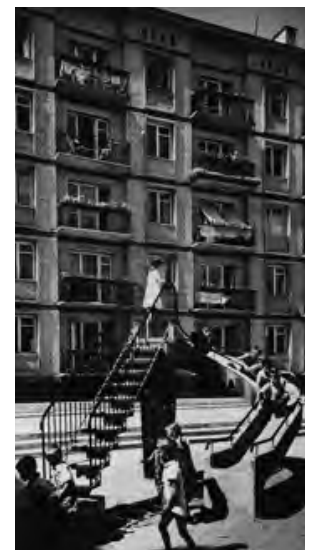

Fot. E. Kupiecki

Wnętrze międzyblokowe

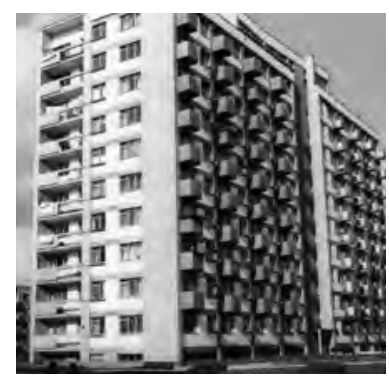

Fot. CAF. Mister Warszawy 1965, Dom przy ul. Magiera

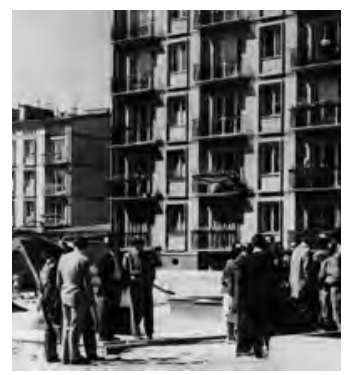

Fot. Wł. Piotrowski Bielany I

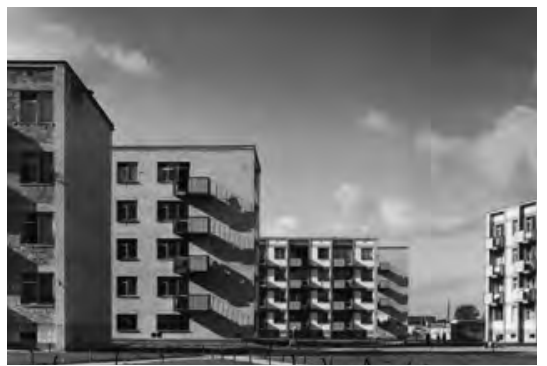

Fot. A. Zborski, Bielany III, 1962

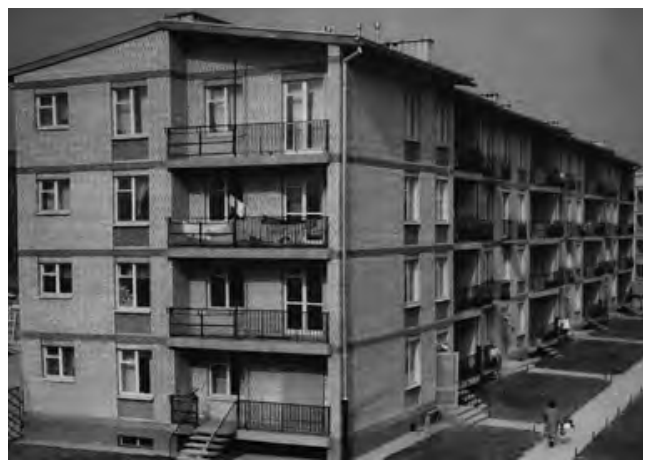

Fot. T. Rolke, Bielany III, 1959

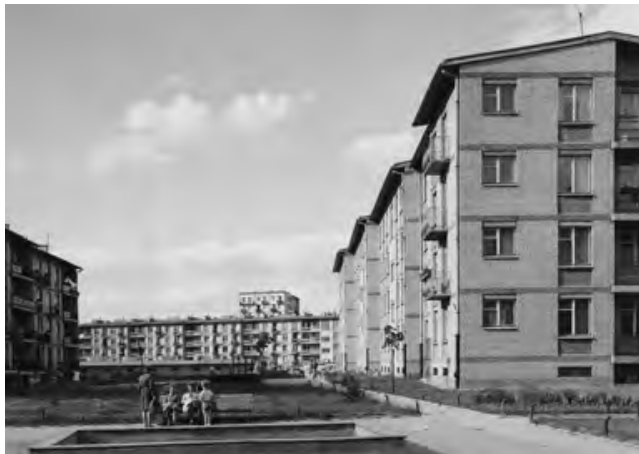

Fot. AN, Bielany II

Ryc. 3. Przykłady realizacji Spółki MiK Piechotkowie na warszawskich Bielanach Źródło: Biblioteka Główna; Politechnika Warszawska 


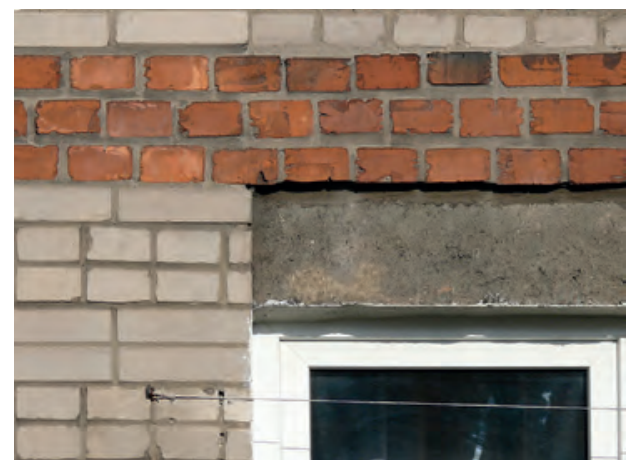

Bielany II, ul. S. Żeromskiego 4 fragment elewacji przed ociepleniem

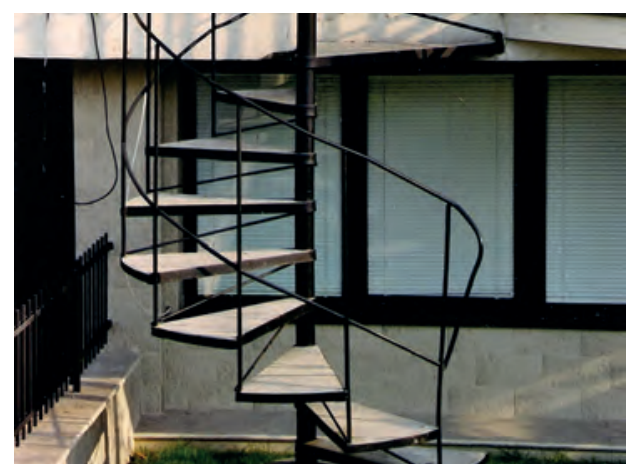

Bielany II, ul. Sentymentalna (obecnie M. Pawlikowskiej-Jasnorzewskiej)

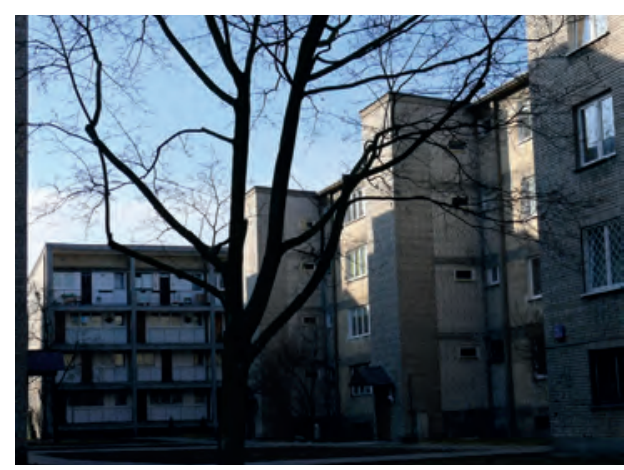

Bielany III, ul. A. Magiera

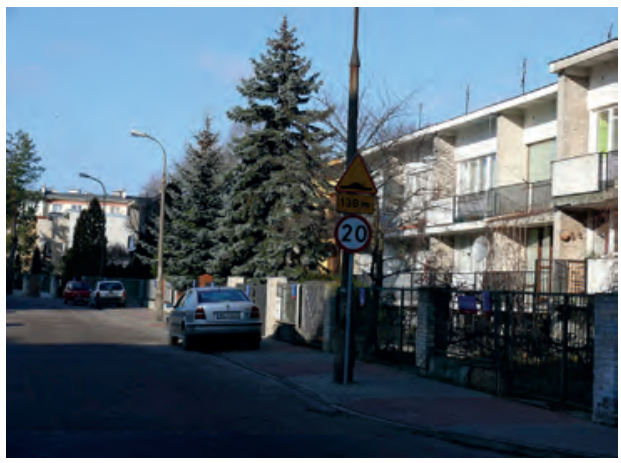

Bielany II, ul. Sentymentalna (obecnie M. Pawlikowskiej Jasnorzewskiej)

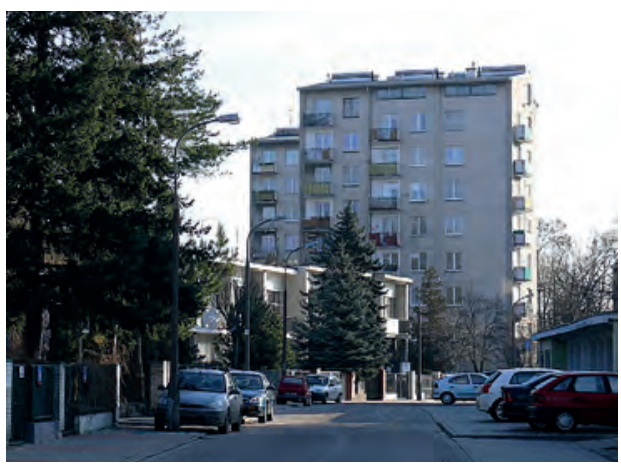

Bielany II, ul. Sentymentalna (obecnie M. Pawlikowskiej-Jasnorzewskiej)

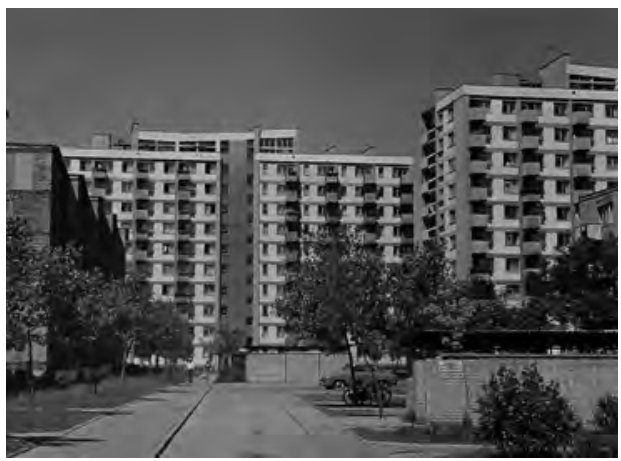

Bielany III, ul. A. Magiera

Ryc. 4. Przykłady realizacji Spółki MiK Piechotkowie na warszawskich Bielanach Fot. M. Piechotka, $z$ archiwum rodzinnego 
Ucieczką od socrealizmu było projektowanie wystaw i dekoracji z okazji kongresów międzynarodowych, w których stosowanie jego zasad nie obowiązywało. Jednocześnie z projektowaniem Bielan, braliśmy udział w projektowaniu wielkich wystaw m.in. Przemysłu Chińskiej Republiki Ludowej u Braci Jabłkowskich, Odrodzenia i Oświecenia w Muzeum Narodowym. Projektowaliśmy dekorację wnętrz Domu Słowa Polskiego na II Światowy Kongres Pokoju i w hallu Politechniki Warszawskiej na I Kongres Nauki Polskiej, dekoracje uliczne Nowego Światu i Krakowskiego Przedmieścia na słynny Światowy Festiwal Młodzieży i Studentów w 1955 r. Jednocześnie, mimo wspomnianego „dobrowolnego” odejścia Macieja z ZAP w 1952 r. nie przerwaliśmy pracy nad książką o bóżnicach drewnianych. Ukazała się jako pierwsza powojenna publikacja ZAP w 1957 r., a w 1959 r. została wydana w przekładzie na język angielski.

W latach 1955-1957 udało nam się zrealizować grupę budynków przy ul. Skalbmierskiej z użyciem m.in. cegły silikatowej na elewacjach. Była już gotowa, kiedy władze Warszawy postanowiły pokazać Biuru Politycznemu PZPR z nowo wybranym I Sekretarzem, Władysławem Gomułką na czele, co i jak się w stolicy buduje. Przyjechali również na Skalbmierska. Jako projektanci musieliśmy być obecni na miejscu, żeby móc na wszelki wypadek udzielić wyjaśnień. I wtedy usłyszeliśmy, jak premier J. Cyrankiewicz powiedział do Gomułki: "Towarzyszu, popatrzcie, Piechotkowie zastosowali lufciki w oknach i socjalizm się nie zawalił". (Obowiązywało w tym czasie stosowanie w całym budownictwie, bez względu na wielkość pomieszczenia, jednego typu okna C2, dwuskrzydłowego bez lufcika). Następnego dnia dostaliśmy z kancelarii premiera zawiadomienie o przyznaniu nam paszportów i stypendium w dewizach na dwutygodniowy wyjazd do Paryża dla zapoznania się z tamtejszym budownictwem mieszkaniowym. Zespół przy Skalbmierskiej został uznany za pierwszy w budownictwie wyłom w socrealizmie. Dostaliśmy za niego nagrodę m.st. Warszawy i nagrodę I stopnia prezesa Komitetu do spraw Urbanistyki i Architektury.

Ale naprawdę szeroko rozumiana problematyką budownictwa mieszkaniowego zaczęliśmy się zajmować po przewrocie październikowym 1956. Wówczas bardzo ożywiła swoja działalność, istniejąca już od początku lat 50. Sekcja Budownictwa Osiedlowego SARP, której Maciej przewodniczył od początku do lat 1970. Działali w niej głównie architekci - mieszkaniowcy warszawscy. My wszyscy, a nieco później również wielu naszych młodszych kolegów mieszkaniowców z całej Polski, byliśmy bardzo zawodowo, społecznie i emocjonalnie zaangażowani w to, co i jak projektujemy. Uważaliśmy, że naszym obowiązkiem jest stworzenie i zapewnienie - w ówczesnych, bardzo trudnych i siermiężnych warunkach technicznych i materiałowych, ograniczeniach ekonomicznych i normatywnych - wszystkim mieszkańcom jak najlepszych warunków życia. Staraliśmy się o poprawę normatywu mieszkaniowego, o tereny wspólnej rekreacji i wypoczynku, o realizację programu towarzyszącego i właściwe rozmieszczenie urządzeń dziecięcych itp.

Pomiędzy 1958 a 1964 r. zaprojektowaliśmy na Bielanach następne cztery osiedla. Były projektowane etapami, najpierw II - tzw. serek Bielański, potem kolejno osiedle przy ul. Magiera, Słodowiec, ostatnie - Osiedle Zjednoczenia. Podobnie jak inne realizowane w tym czasie osiedla były one stosunkowo niewielkie, każde na ok. 10 tys. mieszkańców. Czas 
wielkich, projektowanych od jednego rzutu jako całość osiedli-dzielnic jeszcze nie nadszedł. Projektowaliśmy je zgodnie z wytycznymi Planu Generalnego Warszawy, zarazem z myśla o istniejącej strukturze miejskiej. Zachowaliśmy zaprojektowany jeszcze przed wojna, promienisty układ ulic i skalę zabudowy. Staraliśmy się nadać każdemu z osiedli inny, dla niego charakterystyczny układ i wyraz architektoniczny zabudowy, jednak otwartej na wspólna przestrzeń publiczna. Ale jedynie dla Serka i osiedli przy Magiera udało nam się zaprojektować urbanistykę wraz z budynkami. Na Słodowcu i Osiedlu Zjednoczenia, musieliśmy już zastosować budynki mieszkalne z warszawskiego katalogu.

W 1965 r. postanowiono przeznaczyć znaczne środki na stworzenie w całym kraju sieci wytwórni elementów wielkopłytowych, wyposażonych w importowane z zagranicy, w tym również ze strefy dolarowej, urządzenia produkcyjne o dużej wydajności i zapewniające znacznie lepszą od dotąd uzyskiwanej jakość wyrobów. Zaistniała obawa, że znów będa to urządzenia o ograniczonym programie produkcji, że cała Polska zostanie zabudowana, teraz już na masową skalę, jednakowymi, wielkopłytowymi „typowcami”. Trzeba było temu za wszelką cenę zapobiec. Zorganizowano ogólnopolski konkurs na projekt systemu budownictwa z betonowych elementów wielkowymiarowych, który, uwzględniając warunki produkcji przemysłowej, transportu i prostotę montażu, zarazem dawałby możliwie duża swobodę kształtowania funkcji i formy architektonicznej budynków. Po pierwszej fazie konkursu, w którym wzięło udział 40 zespołów z całej Polski, zdecydowano się dla kilku pierwszych wytwórni, których oprzyrządowanie miało być zakupione w ZSRR przyją́ tzw. System Szczeciński. W drugiej fazie konkursu, wybrano do realizacji nasz „System otwarty budownictwa z elementów wielkowymiarowych W 70".

Istota systemu W 70 było wprowadzenie, produkowanych w odpowiednio skonstruowanych formach, typoszeregów podstawowych, obojętnych pod względem architektonicznym elementów budowlanych - ścian, stropów, biegów schodowych, płyt dachowych, o wymiarach zgodnych z obowiązującą w normach międzynarodowych koordynacją modularną oraz sposobu ich zestawiania, tj. kształtowania złączy, pozwalającego na dużą swobodę w kształtowaniu funkcji i bryły budynków. Sposób wykorzystania systemu i detal architektoniczny budynku, zależy od potrzeb oraz od chęci, umiejętności i inwencji twórczej autorów i projektantów konkretnych realizacji.

Wytwórnie elementów Systemu W 70 lub Wk 70 powstały w całym kraju. Zgodnie z pierwotnym założeniem powstawały jego mutacje projektowane przez architektów konkretnych realizacji, jak np. Tychy, Nowe Miasto Zamość, czy warszawski Ursynów. Jedynym zrealizowanym z elementów systemu na podstawie naszego projektu, jest niewielki zespół domków jednorodzinnych na obrzeżach Ursynowa. Nasze projekty koncepcyjne zespołu mieszkaniowego Nowo Bema w Warszawie oraz hoteli Orbis w Gdyni i Łodzi pozostały na papierze. W latach 1977-1979, rozwijając metodologię przyjętą w W 70/Wk 70 opracowaliśmy założenia i koncepcję otwartego systemu ECA dla Algierii, uwzględniającego tamtejsze tradycje architektoniczne, potrzeby użytkowe, warunki klimatyczne i zagrożenia sejsmiczne.

Jest rzeczą oczywista, że przez cały ten czas nie pracowaliśmy sami. Mieliśmy duża wielobranżowa pracownię, której skład się z biegiem czasu zmieniał. Nie sposób wymienić 
wszystkich - tak wielu ich było. Serdecznie im dziękujemy. Równocześnie w latach 1973 -1974 opracowaliśmy już sami we dwoje „Koncepcję, założenia wyjściowe i program prac” nad integracją budownictwa ogólnego IS, zatwierdzone przez Ministerstwo Budownictwa i Przemysłu Materiałów Budowlanych w 1976 r.

W 1980 r. okazało się, że wobec ukończenia 60 lat chcąc nie chcąc, w środku pracy nad IS, muszę iść na emeryturę. Maciej skorzystał z uprawnień kombatanckich i odszedł kilka miesięcy później. Ostatnim zadaniem, jakie nam się udało ukończyć przed definitywnym opuszczeniem biura były "Zasady ogólne IS”. Zostały wydane w formie książkowej przez COBPBO w 1984 r. Ale wkrótce wszystko się zmieniło i stały się zupełnie nieaktualne.

W tym samym, 1984 r. dostaliśmy od Instytutu Sztuki PAN propozycję udziału w programie rządowym „Architektura i sztuka żydowska”. Był to powrót do tej tematyki po 30 latach przerwy, jaka upłynęła od ukazania się naszej książki pt. „Bóżnice Drewniane”. Rozpoczął się w naszym życiu nowy, dwudziestoczteroletni etap, w którym powstały nasze trzy nowe książki poświęcone architekturze i sztuce bóżniczej na tle dziejów osadnictwa żydowskiego na terenach dawnej Rzeczypospolitej (ryc. 5 i 6):

- Bramy nieba. Bóżnice drewniane na ziemiach dawnej Rzeczypospolitej, Wydawnictwo Krupski i S-ka, Warszawa 1996.

- Wydanie angielskie: Heaven Gates. Wooden synagogues in the territories of the former PolishLithuanian Commonwealth, Wydawnictwo Krupski i S-ka, Warszawa 2004.

- Bramy nieba. Bóżnice murowane na ziemiach dawnej Rzeczypospolitej, Wydawnictwo Krupski i S-ka, Warszawa 1999.

- Oppidum Judaeorum: Żydzi w przestrzeni miejskiej dawnej Rzeczypospolitej, Wydawnictwo Krupski i S-ka, Warszawa 2004 - oraz liczne referaty, wykłady i wystapienia na konferencjach w kraju i zagranica.

- Ostatnia, czwarta książka pt. - Krajobraz z Menora ma się ukazać jeszcze w tym miesiącu i stanowić będzie zakończenie naszych 70 lat z Architektura".

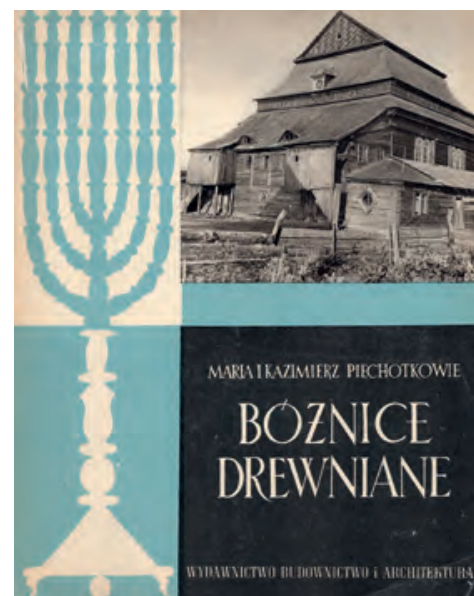

Ryc. 5. Bóżnice Drewniane, okładka

Źródło: $z$ archiwum rodzinnego

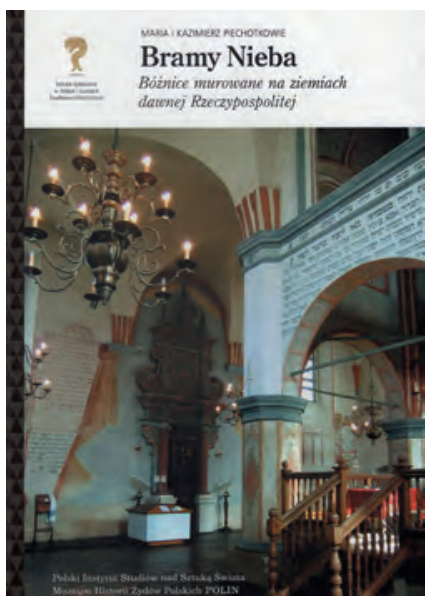

Ryc. 6. Bramy Nieba, okładka

Źródło: $z$ archiwum rodzinnego 
Po wystawie nadal prowadzili prace nad architekturą i urbanistyką żydowska. Po śmierci męża w 2010 r. Maria sama, kontynuowała razem rozpoczęte prace. M.in. w 2015 r. we współpracy z wydawnictwem Salix Alba przygotowała wydanie angielskiej wersji książki Krajobraz z Menora pt. Landscape with a Menorah.

Na potrzeby Polskiego Instytutu Badań nad Sztuką Świata na nowo opracowała rozszerzone wersje wszystkich trzech książek poświęconych architekturze i osadnictwu żydowskiemu. We współpracy PIBnSŚ (Polski Instytut Badań nad Sztuką Świata) i Muzeum POLIN zostały wydane po polsku i po angielsku, w serii Sztuka żydowska w Polsce i Europie Środkowo-Wschodniej. Są to książki: Bramy nieba. Bóżnice drewniane na ziemiach dawnej Rzeczypospolitej, Warszawa 2015; Bramy nieba. Bóżnice murowane na ziemiach dawnej Rzeczypospolitej, Warszawa 2017; i przygotowana do druku Oppidum Judaeorum. Żydzi w przestrzeni miejskiej dawnej Rzeczypospolitej.

Michał Piechotka, ur. 1948 r. w Krakowie, mgr inż. arch., dyplom Wydziału Architektury Politechniki Warszawskiej. Pracownik biur i pracowni projektowych w Warszawie i Algierii. Autor i współautor szeregu opracowań studyjnych, projektowych, realizacji architektury i wystaw. W latach 1989-2005 pracownik urzędów administracji architektoniczno-budowlanej. Członek SARP (Stowarzyszenie Architektów Polskich).

Michat Piechotka, born in 1948 in Cracow, MSc in architecture, diploma of the Faculty of Architecture, Warsaw University of Technology. Employee of design offices and studios in Warsaw and Algeria. Author and co-author of a number of studies, projects, architectural realizations and exhibitions. In the years 1989-2005 employee of architectural and construction administration offices. Member of SARP (the Association of Polish Architects).

Maciej Piechotka, ur. 1952 r. w Warszawie, mgr inż. arch., dyplom Wydziału Architektury Politechniki Warszawskiej. Pracownik biur i pracowni projektowych, autor szeregu realizacji. W latach 1981-1986 wykładowca na Uniwersytecie Nigieryjskm, na Wydziale Architektury. Członek SARP (Stowarzyszenie Architektów Polskich) i MOIA RP (Mazowiecka Okręgowa Izba Architektów Rzeczypospolitej Polskiej).

Maciej Piechotka, born in 1952 in Warsaw, MSc in architecture, diploma of the Faculty of Architecture, Warsaw University of Technology. Employee of design offices and studios, author of a number of projects. In the years 1981-1986 lecturer at the Department of Architecture, University of Nigeria. Member of SARP (the Association of Polish Architects) and MOIA RP (Mazovian Regional Chamber of Polish Architects). 